\title{
Diabetes mellitus and lung function tests
}

\author{
Dhaher J. S. Al-Habbo*, Afraa M. Al-Ameen** \\ * Department of Medicine;** Department of Physiology, College of Medicine, University of Mosul.
}

(Ann. Coll. Med. Mosul 2012; 38 (1): 27-32).

Received: $20^{\text {th }}$ Mar. 2011; Accepted: $26^{\text {th }}$ Oct. 2011.

\begin{abstract}
Objective: To measure the effects of type 1 and type 2 diabetes mellitus on the various spirometric pulmonary function tests

Methods: This study involved 70 diabetic patients, 25 type 1 and 45 type 2 diabetes mellitus, and 45 control group. Type 1 diabetic patients included 14 males and 11 females, their ages ranging from 1763 years with their mean was 47.12, with SD12.83. Type 2 diabetic patients included 26 males and 19 females; their ages ranging from 19-63 years with their mean 46.67, with SD 9.50. The control group involved 24 males and 21 females, their ages ranging from 13-68 years with their mean 38.78, with SD13.3.

The study was conducted in Ibn Sena Teaching Hospital - Medical Outpatient Clinic, Al-wafa Medical Center in Mosul, and Mosul University-Medical Center.

Results: There were statistically significant differences between the control group and type 1 diabetes mellitus during the measurements of FVC\%, FEV1/FVC\% and MMFR\%, with statistically significant reductions in their values when compared to controls. Furthermore, type 2 diabetes mellitus has significant effects on FVC\%, FEV1 and FEV1/FVC\% when compared with the controls, with statistically significant differences from the control group. There were no much differences between them apart from the FVC\% which favors type 1 diabetes mellitus over type 2 diabetes mellitus with highly significant $P$-value.

Conclusion: The present study clearly indicates that both type 1 and type 2 diabetes mellitus adversely affects the various pulmonary function tests, and the results are in accord with other previous studies.
\end{abstract}

Keywords: Spirometry, diabetes mellitus various types.

الخلاصة

الأهداف: لقياس نأثثير داء السكري المعتمد في المعالجة على الأنسولين وكذلك داء السكري المعتمد على الحبوب عن طريق الفم على الفحوصات المختلفة لوظائف الرئة.

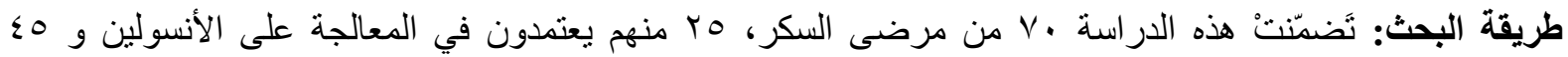

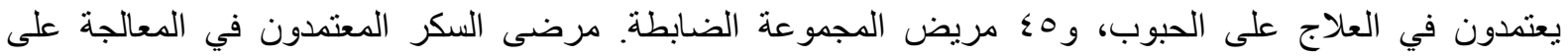

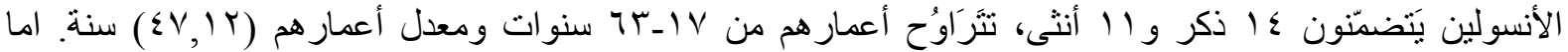

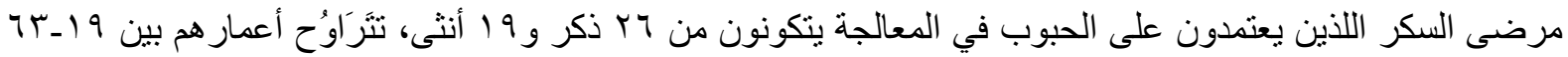

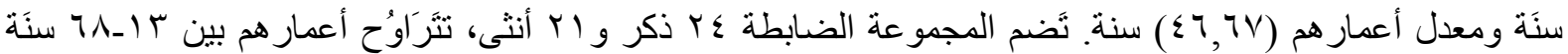

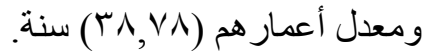

مكان إجراء البحث: جرى البحث في مستشفى ابن سينا التعليمي- العيادة الاستشارية، مركز الوفاء لمعالجة السكر وكذللك

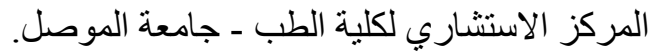


النتائج: كانت هنالك فروقات معنوية بين المرضى للنوع الأول و النوع الثاني من مرضى السكر و المجمو عة الضابطة عند قياس FVC\%, FEV1/FVC\% and MMF مع انخفاض في القيم الاحصائية لهذه الفحوصات. لم يكن هناللك فروقات

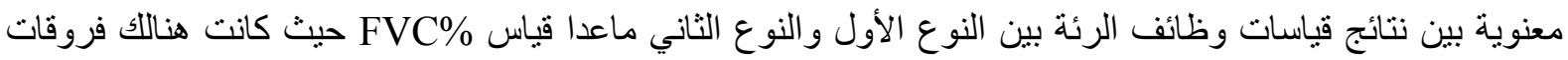

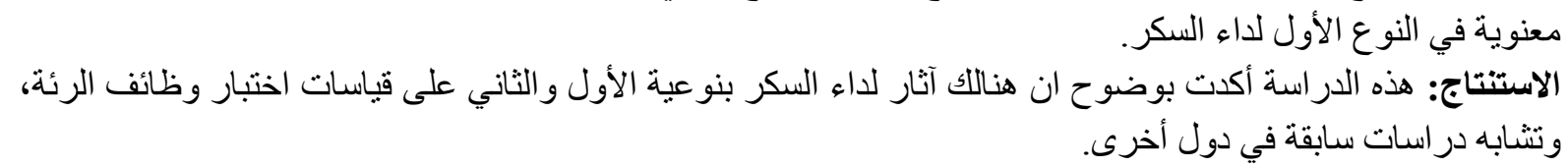

$\mathrm{T}$ he lung can be considered as one of the end organs which can be adversely affected by diabetes; reduced lung function may occasionally be present even before the clinical recognition of diabetes although it will not be the presenting symptom ${ }^{(1)}$, suggesting that the lung may be involved in the pathogenesis of diabetes.

There is growing evidence which supports the association between reduced lung function and diabetes ${ }^{(2)}$. The improvements in lung function following intensive insulin therapy ${ }^{(3)}$ support the concept that the lung may be a target organ for damage in diabetes.

Diabetes has been associated with asthma at the population level ${ }^{(4)}$, suggesting that despite their immunological differences, susceptibility to diabetes and asthma may be influenced by common environmental factors.

The large size alveolar-capillary network is protected against gross respiratory complications at a given level of systemic microvascular destruction. Therefore lung function tests could provide useful measures to follow the progress of systemic microangiopathy in diabetics. ${ }^{(5)}$

In diabetic patients forced expiratory volume in the first second (FEV1) declines at twice the physiological rate regardless of the presence of documented autonomic neuropathy. ${ }^{(6)}$

Patients with diabetes without a smoking history or clinical lung disease consistently demonstrate a modest restrictive ventilator defect with proportional (8-20\%) reductions in lung volume, forced vital capacity (FVC), FEV1, and forced expiratory flow in the midrange of vital capacity compared to subjects without diabetes ${ }^{(7)}$ and in relation to glycemic control. ${ }^{(8)}$ Total lung capacity, lung elastic recoil, and dynamic lung compliance were abnormally reduced in type 1 diabetes. ${ }^{(9)}$

The aims of this study are to measure the effects of type 1 and type 2 diabetes mellitus on the various spirometric tests and also to study the effect of the duration of diabetes mellitus, the age and sex of the patient on these various tests.

\section{Patients and methods}

This study involved 70 diabetic patients 25 type 1 and 45 type 2 diabetes mellitus, and 45 control group. Type 1 diabetic patients included 14 men and 11 women, their ages ranging from 17-63 years with their mean 47.12 with SD 12.83. Type 2 diabetic patients included 26 men and 19 women; their ages ranging from 19-63 years with their mean 46.67 and with SD 9.50. The control group involved 24 men and 21 women, their ages ranging from 13-68 years with their mean 38.78 with SD13.3.

The exclusion criteria were as follows: Patients with known history of acute or chronic respiratory infections which may interfere with lung function tests, neuromuscular disease, cardiopulmonary disease and those who had undergone chest surgery or other major operations. Subjects with history of smoking and patients with gross abnormalities of the thoracic cage which may interfere with lung function test were also excluded from the study. Furthermore patients with overt diabetic neuropathy, retinopathy and nephropathy were also excluded from the study.

All the spirometric measurements were carried out in the outpatient department of IbnSena Teaching Hospital during the early morning, while the subjects were in standing position. All the measurements were done by 
using DISCOM 14 Spirometer (Germany). Most patients were referred from Al-wafa Medical Center in Mosul, and the private clinics of the authors.

The following pulmonary function tests were carried out for the patients and the controls: Forced Vital Capacity (FVC), Forced Expiratory Volume in first second $\left(F_{E V}\right)$, Forced Expiratory Ratio ( $F E V_{1} / F V C$ ), Forced Expiratory Flow (FEF $25-75 \%$ MMFR) and Peak Expiratory Flow (PEF), with calculation of their percentage of predictive values.

\section{Statistical analysis}

The various lung function tests were reported in absolute volume as well as the per cent of their predicted values, the percent of predicted values were mostly used in the statistical analysis. After calculation of the mean and the standard deviation, the statistical analysis was conducted using unpaired T-test to compare the lung function tests values in type 1 and type 2 diabetes mellitus with the control group. The level of significance was taken as $p<0.025$.

\section{Results}

To study the effects of diabetes mellitus on the various lung function tests, we compared the effects of type 1 diabetes mellitus on the lung function tests by comparing it with the control group as in table (1).

There were statistically significant differences between the control group and type 1 diabetes mellitus during the measurements of FVC\%, FEV1/FVC\% and MMFR\%, with statistically significant reductions in their values when compared with the controls. These results prove that type 1 diabetes mellitus patients have significant effects on the various lung function tests as restrictive pulmonary defect and even obstructive ventilator defect.

Furthermore, we compared the effects of type 2 diabetes mellitus on the lung function tests by comparing it with the control group as in table (2).

These results asserting that type 2 diabetes mellitus has significant effects on many lung function tests as compared with the controls, especially during the measurements of $\mathrm{FVC} \%$, FEV1 and FEV1/FVC\% with statistically significant differences between the control group and type 2 diabetes mellitus, with statistically significant reductions in the value of these tests when we compare them with the control group. All these result go with restrictive pulmonary defect.

To determine the difference between type 1 and type 2 diabetes mellitus and their effects on the various lung function tests, we studied the differences between them as in table (3) by using unpaired T-test, this type of study indicates that there were no much differences between them apart from the FVC\% which favors type 1 diabetes mellitus over type 2 diabetes mellitus with highly significant $\mathrm{P}$-value as shown below in table (3). This test indicates that type 1 and type 2 diabetes mellitus have similar effect on the various lung function tests.

The duration of diabetes in the two groups seems to have no significant effects on the lung function tests values, as most of the patients in the sample studied had their diabetes mellitus duration less than 10 years, apart from 5 patients in type 1 and 5 patients in type 2 diabetes mellitus as seen in table (4).

Table (1): Comparison the lung function in type 1 diabetes mellitus and controls.

\begin{tabular}{|c|c|c|c|c|c|}
\hline Type & $\begin{array}{c}\text { Test type \%of } \\
\text { predictive value }\end{array}$ & $\begin{array}{c}\text { Number of } \\
\text { patients }\end{array}$ & Mean & SD & $P$ value \\
\hline $\begin{array}{l}\text { Type } 1 \text { Diabetes } \\
\text { Control Group }\end{array}$ & FVC\% & $\begin{array}{l}25 \\
45\end{array}$ & $\begin{array}{l}79.7 \\
90.5\end{array}$ & $\begin{array}{l}15.9 \\
10.3\end{array}$ & 0.001 \\
\hline $\begin{array}{l}\text { Type } 1 \text { Diabetes } \\
\text { Control Group }\end{array}$ & FEV1\% & $\begin{array}{l}25 \\
45\end{array}$ & $\begin{array}{l}88.5 \\
87.9\end{array}$ & $\begin{array}{l}6.7 \\
5.8\end{array}$ & $0.714(\mathrm{~N})$ \\
\hline $\begin{array}{l}\text { Type } 1 \text { Diabetes } \\
\text { Control Group }\end{array}$ & FEV1/FVC\% & $\begin{array}{l}25 \\
45\end{array}$ & $\begin{array}{l}71.6 \\
84.4\end{array}$ & $\begin{array}{c}13.9 \\
8.9\end{array}$ & 0.000 \\
\hline $\begin{array}{l}\text { Type } 1 \text { Diabetes } \\
\text { Control Group }\end{array}$ & MMFR\% & $\begin{array}{l}25 \\
45\end{array}$ & $\begin{array}{l}87.2 \\
97.8\end{array}$ & $\begin{array}{l}20.5 \\
14.5\end{array}$ & 0.014 \\
\hline $\begin{array}{l}\text { Type } 1 \text { Diabetes } \\
\text { Control Group }\end{array}$ & PEFR\% & $\begin{array}{l}25 \\
45\end{array}$ & $\begin{array}{l}84.5 \\
87.6\end{array}$ & $\begin{array}{l}12.4 \\
10.8\end{array}$ & $0.265(\mathrm{~N})$ \\
\hline
\end{tabular}


Table (2): Comparison the lung function in type 2 diabetes mellitus and controls.

\begin{tabular}{|c|c|c|c|c|c|}
\hline Type & $\begin{array}{c}\text { Test type \%of } \\
\text { predictive value }\end{array}$ & $\begin{array}{l}\text { Number of } \\
\text { patients }\end{array}$ & Mean & $\mathrm{SD}$ & $P$ value \\
\hline $\begin{array}{l}\text { Type } 2 \text { Diabetes } \\
\text { Control Group }\end{array}$ & FVC\% & $\begin{array}{l}45 \\
45\end{array}$ & $\begin{array}{l}95.0 \\
90.5\end{array}$ & $\begin{array}{l}13.5 \\
10.3\end{array}$ & 0.077 \\
\hline $\begin{array}{l}\text { Type } 2 \text { Diabetes } \\
\text { Control Group }\end{array}$ & FEV1\% & $\begin{array}{l}45 \\
45\end{array}$ & $\begin{array}{c}84.4 \\
100.7\end{array}$ & $\begin{array}{c}8.7 \\
18.7\end{array}$ & 0.027 \\
\hline $\begin{array}{l}\text { Type } 2 \text { Diabetes } \\
\text { Control Group }\end{array}$ & FEV1/FVC\% & $\begin{array}{l}45 \\
45\end{array}$ & $\begin{array}{l}76.3 \\
84.4\end{array}$ & $\begin{array}{l}7.2 \\
8.9\end{array}$ & 0.000 \\
\hline $\begin{array}{l}\text { Type } 2 \text { Diabetes } \\
\text { Control Group }\end{array}$ & MMFR\% & $\begin{array}{l}45 \\
45\end{array}$ & $\begin{array}{l}95.1 \\
97.8\end{array}$ & $\begin{array}{l}24.5 \\
14.5\end{array}$ & $0.385(\mathrm{~N})$ \\
\hline $\begin{array}{l}\text { Type } 2 \text { Diabetes } \\
\text { Control Group }\end{array}$ & PEFR\% & $\begin{array}{l}45 \\
45\end{array}$ & $\begin{array}{l}88.4 \\
87.8\end{array}$ & $\begin{array}{l}11.9 \\
10.8\end{array}$ & $0.775(\mathrm{~N})$ \\
\hline
\end{tabular}

Table (3): Comparison the lung function in type 1 and type 2 diabetes mellitus.

\begin{tabular}{|c|c|c|c|c|c|}
\hline Type & $\begin{array}{c}\text { Test type \%of } \\
\text { predictive value }\end{array}$ & $\begin{array}{c}\text { Number of } \\
\text { patients }\end{array}$ & Mean & SD & $P$ value \\
\hline $\begin{array}{l}\text { Type } 1 \text { Diabetes } \\
\text { Type } 2 \text { Diabetes }\end{array}$ & FVC\% & $\begin{array}{l}25 \\
45\end{array}$ & $\begin{array}{c}79.7 \\
95.00\end{array}$ & $\begin{array}{l}15.9 \\
13.5\end{array}$ & 0.000 \\
\hline $\begin{array}{l}\text { Type } 1 \text { Diabetes } \\
\text { Type } 2 \text { Diabetes }\end{array}$ & FEV1\% & $\begin{array}{l}25 \\
45\end{array}$ & $\begin{array}{l}88.5 \\
84.4\end{array}$ & $\begin{array}{l}6.7 \\
8.7\end{array}$ & $0.063(\mathrm{~N})$ \\
\hline $\begin{array}{l}\text { Type } 1 \text { Diabetes } \\
\text { Type } 2 \text { Diabetes }\end{array}$ & FEV1/FVC\% & $\begin{array}{l}25 \\
45\end{array}$ & $\begin{array}{l}71.6 \\
76.3\end{array}$ & $\begin{array}{l}13.9 \\
7.20\end{array}$ & $0.062(\mathrm{~N})$ \\
\hline $\begin{array}{l}\text { Type } 1 \text { Diabetes } \\
\text { Type } 2 \text { Diabetes }\end{array}$ & MMFR\% & $\begin{array}{l}25 \\
45\end{array}$ & $\begin{array}{l}87.2 \\
94.1\end{array}$ & $\begin{array}{l}20.5 \\
24.5\end{array}$ & $0.234(\mathrm{~N})$ \\
\hline $\begin{array}{l}\text { Type } 1 \text { Diabetes } \\
\text { Type } 2 \text { Diabetes }\end{array}$ & PEFR\% & $\begin{array}{l}25 \\
45\end{array}$ & $\begin{array}{l}84.5 \\
88.4\end{array}$ & $\begin{array}{l}12.4 \\
11.9\end{array}$ & $0.201(\mathrm{~N})$ \\
\hline
\end{tabular}

Table (4): The effects of duration of diabetes mellitus on the lung function tests.

\begin{tabular}{|l|c|c|c|c|}
\hline & Mean Type 1 DM & Mean Type 2 DM & SD Type 1 & SD Type 2 \\
\hline FVC\% & 79.7 & 95 & 15.9 & 13.6 \\
\hline FEV1\% & 88.5 & 84.4 & 6.7 & 8.7 \\
\hline FEV1/FVC\% & 71.6 & 76.3 & 13.9 & 7.2 \\
\hline MMFR\% & 87.0 & 94 & 20.6 & 24.5 \\
\hline PEFR\% & 84.6 & 88.4 & 12.4 & 11.9 \\
\hline Duration & 5.5 & 6.7 & 4.0 & 5.6 \\
\hline Number of patients & 25 & 45 & & \\
\hline
\end{tabular}

\section{Discussion}

Pulmonary indices are largely independent of physical fitness and the secondary sequel of diabetic end-organ failure usually does not interfere with the interpretation of the various lung function tests ${ }^{(10)}$. Therefore this study 
depends on spirometric measurement to assess the effect of diabetes mellitus on lung function test.

Williams JG and others since 1984 demonstrated that more than one third of patients with diabetes showed abnormal ventilator response to exercise, hypercapnia, or hypoxia consistent with autonomic neuropathy. ${ }^{(5)}$

The present study demonstrates that type 1 diabetes mellitus has significant effects on the lung function tests during the measurements of FVC\%, FEV1/FVC\% and MMFR\%, with statistically significant reductions in their values when compared with the controls, but FEV1\% and PEFR\% were more or less the same as the control group. These results are consistent with the findings by Sandler $M$ and others (11). However, Benbassat and coworkers showed that FVC, $\mathrm{FEV}_{1}$, and MMFR\% were within the predicted values in both type 1 and type 2 diabetes populations (12). Furthermore they compared the effects of type 1 and type 2 diabetes mellitus on the various lung function tests and they showed nonsignificant differences in $\mathrm{FEV}_{1}$ and MMFR\%, but they did not compare their results with the matched control group, this is the most probable reason for this contradiction with the present study ${ }^{(12)}$.

Furthermore type 2 diabetes mellitus, as demonstrated in this study, has significant effects on many lung function tests as compared with the controls, especially during the measurements of FVC\%, FEV1 and FEV1/FVC\% with statistically significant reductions in the value of these tests. These abnormalities in the lung function tests in this study were the same as what Davis WA and others founds in their study ${ }^{(7)}$.

When we compared the effects of type 1 and type 2 diabetes mellitus on the various lung function tests, there were no much differences between them apart from the FVC\% which favors type 1 diabetes mellitus over type 2 diabetes mellitus with highly significant $\mathrm{P}$ value.

This test indicates that type 1 and type 2 diabetes mellitus have more or less similar effects on the various lung function tests.
These findings were the same as in other studies ${ }^{(13,14)}$.

The duration of diabetes in the two groups in the present study seems to have no significant effects on the lung function tests values as most of the patients in the sample studied had their diabetes mellitus duration less than 10 years apart from 5 patients in type 1 and 5 patients in type 2 diabetes mellitus.

Meo SA et al demonstrated in their study that the duration of diabetes in both type 1 and type 2 diabetes mellitus had no significant effects on the lung function tests when the duration of diabetes mellitus is less than 10 years. On the other hand, when the duration of diabetes was more than 10 years or particularly more than 12 years they found statistically significant effects on the various lung function tests ${ }^{(15)}$.

The present study clearly indicates that both type 1 and type 2 diabetes mellitus adversely affect the various pulmonary function tests, and the results are in accord with other previous studies. Analysis of our data demonstrated poor correlation between the number of years of diabetes mellitus and the decline in lung function tests, mostly due to the fact that most of the patients in the present study had their disease for less than 10 years. Even though it is advisable that physicians should think about the lungs as potential targets for end-organ damage in diabetes. For these reasons it is recommended that patients with diabetes should have periodic spirometry measurement to assess their extent of impaired pulmonary function. These measures will recognize early stages of pulmonary defect, which will help to lower the morbidity and mortality of diabetes.

\section{Conclusion}

Type 1 and type 2 diabetes mellitus adversely affect the various pulmonary function tests. Both types of diabetes cause restrictive ventilator defect. It is probably useful that patients with diabetes should have periodic spirometry measurement to assess the extent of impairment in the pulmonary function tests. These measures will recognize early stages of pulmonary defect, which may help to lower the 
morbidity and mortality of patients with diabetes secondary to lung function defect.

\section{Acknowledgment}

The authors thank all the staff of respiratory function lab in Ibn-Sena Teaching Hospital, and all the staff of Al-wafa medical center in Mosul for their great help.

The authors also thank Miss Mona Moneer who did all the statistical analysis of the data in this study.

\section{References}

1. Engstrom GM, Janzon L. Risk of developing diabetes is inversely related to lung function: a population-based cohort study. Diabet Med 2002;19:167-170.

2. Goldman MD. Lung dysfunction in diabetes. Diabetes Care 2003; 26:19151918.

3. Niranjan V, McBrayer DG, Ramirez LC, Raskin P, Hsia CC. Glycemic control and cardiopulmonary function in patients with insulin-dependent diabetes. Am J Med 1997;103:504-513.

4. Stene L, Nafstad P. Relation between occurrence of type 1 diabetes and asthma. Lancet 2001;357:607-608.

5. Williams JG, Morris Al, Hayter RC, Ogilvie CM. Respiratory responses of diabetics to hypoxia, hypercapnia and exercise. Thorax 1984; 39:529-534.

6. Antonelli $\mathrm{R}$, Fuso $\mathrm{L}$, Pitocco $\mathrm{D}$, et al. Decline of neuroadrenergic bronchial innervation and respiratory function in type 1 diabetes mellitus: a longitudinal study. Diabetes Metab Res Rev 2006; 23:311316.

7. Davis WA, Knuiman M, Kendall $\mathrm{P}$, Grange $V$, Davis TM. Glycemic exposure is associated with reduced pulmonary function in type 2 diabetes: the Fremantle Diabetes Study. Diabetes Care 2004; 27: 752-757.
8. Walter RE, Beiser A, Givelber RJ, O'Connor GT, Gottlieb DJ. Association between glycemic state and lung function: the Framingham Heart Study. Am J Respir Crit Care Med 2003;167:911-916.

9. Schuyler MR, Niewoehner DE, Inkley SR, Kohn R. Abnormal lung elasticity in juvenile diabetes mellitus. Am Rev Respir Dis 1976;113:37-41.

10. Hsia CC, Raskin P. Lung function changes related to diabetes mellitus. Diabetes Technol Ther. 2007; 9 (1): 73-82.

11. Sandler M, Bunn AE, Stewart RI. Pulmonary function in young insulindependent diabetic subjects. Chest 1986; 90:670-675.

12. Benbassat CA, Stern E, Kramer $M$, Lebzelter J, Blum I, Fink G. Pulmonary function in patients with diabetes mellitus. Am J Med Sci. 2001; 322(3): 127-132.

13. Strojek K, Ziora D, Sroczynski JW, Oklek K. Pulmonary complications of type 1 (insulin-dependent) diabetic patients. Diabetologia 1992; 35:1173-1176.

14. Katoh J, Hara Y, Kurusu M, Miyaji J, Narutaki K. Cardiorespiratory function as assessed by exercise testing in patients with non-insulin-dependent diabetes mellitus. J Int Med Res 1996; 24:209-213.

15. Meo SA, Al Drees MA, Ahmed J, et al. Effects of duration of disease on a ventilatory function in an ethnic group of diabetic patients. J Diabetes Sci Technol 2007; 1(5): 711-717. 